\title{
Social capital role in the utilization of mangrove ecosystem service for ecotourism on Kutai National Park, East Kalimantan, Indonesia
}

\author{
IIN SUMBADA SULISTYORINI ${ }^{1, \bullet}$, ERNY POEDJIRAHAJOE ${ }^{2}$, LIES RAHAYU WIJAYANTI FAIDA ${ }^{2}$, \\ RIS HADI PURWANTO ${ }^{3}$ \\ ${ }^{1}$ Forest Resources Conservation, Program of Forestry, Sekolah Tinggi Pertanian Kutai Timur. Jl. Ahmad Dahlan, Bebika Number 18, Sanggatta Utara, \\ East Kutai District 75611, East Kalimantan Province, Indonesia. `email: iinsumbada@ stiperkutim.ac.id \\ ${ }^{2}$ Department of Forest Resources Conservation, Faculty of Forestry, Universitas Gadjah Mada. Sleman 55281, Yogyakarta, Indonesia \\ ${ }^{3}$ Department of Forest Management, Faculty of Forestry, Universitas Gadjah Mada. Sleman 55281, Yogyakarta, Indonesia
}

Manuscript received: 3 July 2018. Revision accepted: 8 October 2018

\begin{abstract}
Sulistyorini IS, Poedjirahajoe E, Faida LRW, Purwanto RH. 2018. Social capital role in the utilization of mangrove ecosystem service for ecotourism on Kutai National Park, East Kalimantan, Indonesia. Bonorowo Wetlands 8: 63-70. Social capital has an important role in mangrove ecosystem preservation. Changes to mangrove ecosystem services can affect elements of social capital. Ecotourism is one of the alternatives that can be developed in the mangrove area in the National Park. The purpose of the study was to give an overview of the correlation between several elements of social capital in supporting ecotourism in mangrove areas. This study was conducted in five villages in East Kutai Regency, East Kalimantan, namely Singa Geweh, Sangkima, Teluk Singkama, Teluk Pandan and Kandolo. There were 530 respondents from the five villages involved as informants or resource persons. The data were analyzed using the Sequal Equation Modeling Partial Least Square (SEM-PLS) method with SmartPLS. Based on the initial assessment by the scoring method, five social capitals, i.e., trust, networking, community involvement, social norm, and concern to mangrove, had low criteria to support ecotourism in Kutai National Park (KNP) mangrove area. According to SEM-PLS analysis of the social capital variables, community involvement, social norms, and trust negatively affected ecotourism. Trust and community involvement were relatively low in the four villages (Singa Geweh, Sangkima, Teluk Singkama, and Kandolo). They were associated with social norms. On the other hand, concern for mangroves, education and income levels, and networking had positive effects and power to support ecosystem service of mangroves for ecotourism.
\end{abstract}

Keywords: Community, ecotourism, East Kalimantan, mangrove preservation

\section{INTRODUCTION}

The mangrove forest area in Indonesia is about 3.1 million hectares, or approximately $22.6 \%$ of the world's mangrove forest area (Giri et al., 2011). In East Kalimantan, the size of mangrove forest is about 367 thousand hectares (Noor et al. 2006). The mangrove forest of Kutai National Park (KNP), located in East Kutai District, East Kalimantan Province, Indonesia, along the coast facing the Makassar Strait, has an area of approximately $5,271.4$ hectares or $2.7 \%$ of the total KNP areas of 192,709.6 hectares (Gunawan and Sayektiningsih 2014). The latest information by the KNP management unit in 2017, the mangrove area is about $4,766.3$ ha or decreased by about $9.6 \%$ from the previous area. Bismark and Iskandar (2002) stated that the mangrove forest of KNP continues to experience pressure due to the increase in human activities for settlement, agriculture, and other activities. Budiarsa and Rizal (2013) explained that mangrove conversion in KNP for various activities has continued over the past two decades. The development of a new regency, especially the East Kutai Regency, is suspected to reduce KNP forests' sustainability on the coast significantly.

The mangrove ecosystem is one of several highproductivity ecosystems (Budihastuti et al., 2012). The primary productivity of mangroves ranges from 350 to 500 grams $\mathrm{C} / \mathrm{m}^{2} / \mathrm{yr}$ in coastal waters, and abroad proportion is founded on the coastline in the tropics (Mann 1982). Mangrove forests also provide valuable ecosystem services for coastal communities, tourist attractions, nature conservation, education, and research (Eddy et al., 2016). The mangrove forest ecosystem of KNP has a high productivity ecosystem role as a source of feed, spawning and conservation areas for aquatic organisms living in the surrounding areas such as fish, crustaceans, mollusks, and others (Budiarsa and Rizal 2014). In addition to the aquatic biota, the KNP mangrove forest is also a habitat for Proboscis Monkey (Nasalis larvatus Wurmb, 1781). It was found in the Sangatta River, French Cape, Sangkima River,, and Kanduung River (Suwarto et al. 2016). Based on this, the KNP mangrove has the potential and opportunities for conservation-based eco-tourism development. Ecotourism is also expected to be used to campaign for the protection and integrity of conservation areas.

Maintaining the existence of mangrove forests in KNP needs a sustainable development of forest utilization based on the ecotourism concept (Daryono 2014). The utilization and management of sustainable mangrove forests require a multi-dimensional and fundamental concept that can affect all categories of ecosystem services (Barnes-Mauthe et al., 
2015), known as social capital. Research on the topic of social capital has gained much attention from researchers around the world, especially in the perspective of collective action (Asmin et al., 2017). The development and changing of socio-cultural conditions of society have provided new challenges in the management of the National Park. This study aimed to provide information for the conservation policy of mangrove forests by exploring the diversity of ecosystem services value for ecotourism based on the importance of social capital, which can be further used as a guideline in the development and utilization of the mangrove forests.

\section{MATERIALS AND METHODS}

\section{Study site description}

Since 2001 the area of KNP has been 198,269 hectares, then in 2014, the area becomes 192,709.6 hectares or decreased about 5,560 hectares. Reduction of the area due to the enclave for settlement community areas such as Teluk Pandan, Kandolo, Teluk Singkama, Sangkima, South Sangatta, and Singa Geweh Village. This study was conducted in five villages located in the coastal regions of KNP. The three villages (Singa Geweh, Sangkima, Teluk Singkama) located in Sangatta Selatan sub-district and two villages (Teluk Pandan and Kandolo) located in Teluk Pandan sub-district on East Kutai Regency, East
Kalimantan (Figure 1). The study period starts from September 2017 to December 2017.

\section{Sampling and data collection}

A direct interview carried out the social capital data of the community in a structured way to the respondents (guidelines with a questionnaire). Respondents were determined proportionally from the number of household heads in the five villages. The total number of respondents from the five villages was 530 households, which was two folds higher than the minimum number of samples/respondents based on the Luck and Rubin formula (Luck and Rubin 1987; Jakpar and Goh, 2012), increasing the validity of the data. Social capital has been conceptualized into three levels, i.e., micro, meso, and macro. The measurement at the micro-level was conducted at the household or individual level (Grootaert et al., 2003). The micro-level measurement (measuring household living standards) became the survey's focus in this study. Data collected included respondents' characteristics: formal education level and income level (X1). Social capital data includes trust (X2), networking (X3), social norm (X4), community involvement (X5), concern to the environment (X6), attitude or perception to the utilization of mangrove for ecotourism (Y1). The seven latent variables and the 35 indicators are described in Table 1.

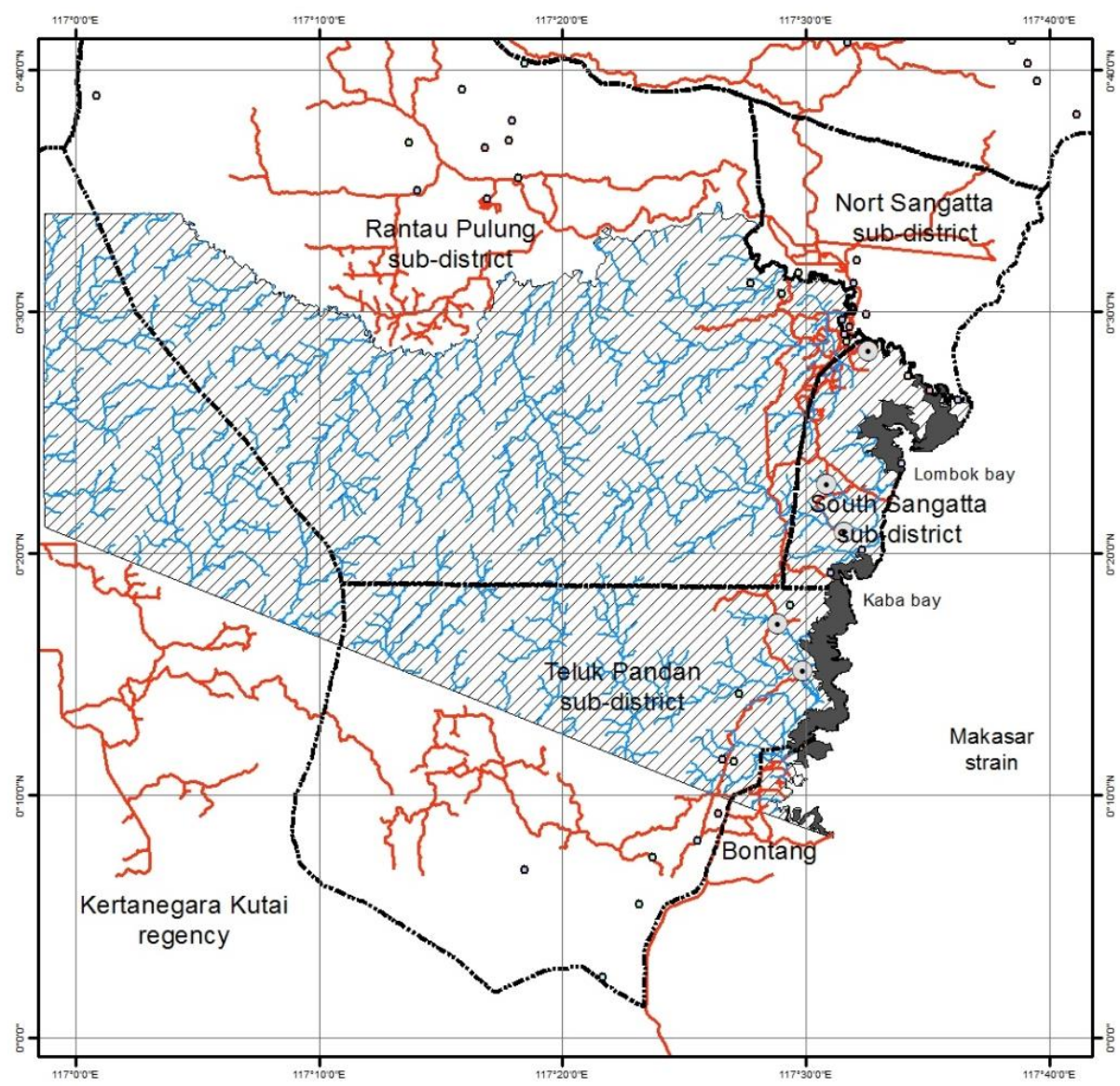

Map of Study Region in Kutai National Park, Indonesia

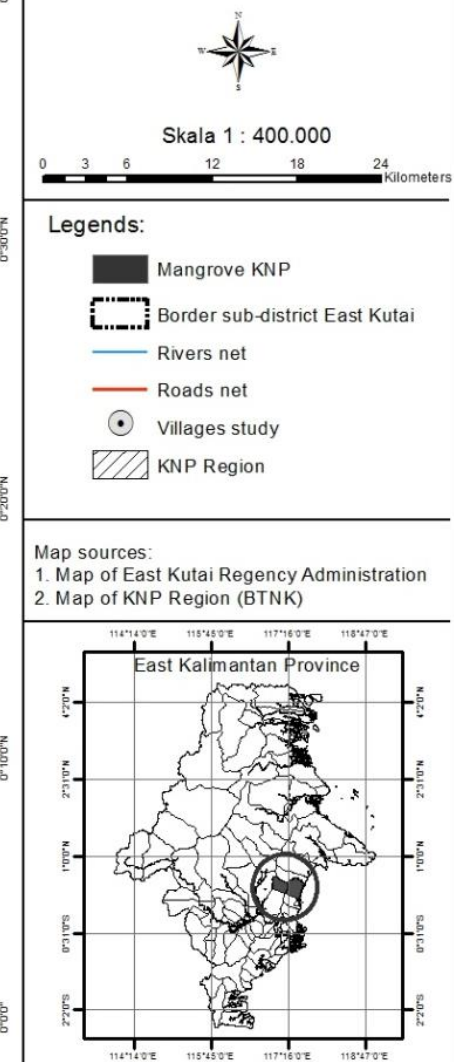

Figure 1. Location of study sites in the mangrove forest of Kutai National Park (KNP), East Kutai District, East Kalimantan, Indonesia 
Table 1. Latent variables and indicators description

\begin{tabular}{|c|c|c|}
\hline Latent variables & Indicator description & \\
\hline \multirow{2}{*}{ Education and income level (X1) } & Education level & $\bar{X} 11$ \\
\hline & Income level & $\mathrm{X} 12$ \\
\hline \multirow[t]{6}{*}{ Trust (X2) } & KNP management unit & $\mathrm{X} 21$ \\
\hline & Local government & $\mathrm{X} 22$ \\
\hline & Social norms/rule traditions & $\mathrm{X} 23$ \\
\hline & Public figure in local society & $\mathrm{X} 24$ \\
\hline & Fellow locals in society & $\mathrm{X} 25$ \\
\hline & Outsiders (NGO/Academics/Researcher) & $\mathrm{X} 26$ \\
\hline \multirow[t]{6}{*}{ Networking and organization (X3) } & Cooperation with KNP management & $\mathrm{X} 31$ \\
\hline & Cooperation with local government & $\mathrm{X} 32$ \\
\hline & Cooperation with Corporate & X33 \\
\hline & Interested with organizations in the local society & X34 \\
\hline & Cooperation fellow local people & $\mathrm{X} 35$ \\
\hline & Leisure to interaction with fellow local & $\mathrm{X} 36$ \\
\hline \multirow[t]{6}{*}{ Social norms (X4) } & Knowledge of social norms & $\mathrm{X} 41$ \\
\hline & Compliance with social norms & $\mathrm{X} 42$ \\
\hline & Obedience and implementing social norms & $\mathrm{X} 43$ \\
\hline & Implementation of agreed rules at the community organization & $\mathrm{X} 44$ \\
\hline & Know and obey the KNP rules & $\mathrm{X} 45$ \\
\hline & Know and follow the local government rules & $\mathrm{X} 46$ \\
\hline \multirow[t]{5}{*}{ Community involvement (X5) } & Follow the meetings initiated by KNP management & $\mathrm{X} 51$ \\
\hline & Participation in community service & $\mathrm{X} 52$ \\
\hline & liveliness in organizations/meetings in the local community & $\mathrm{X} 53$ \\
\hline & liveliness in criticizing to KNP and local government in mangrove management & $\mathrm{X} 54$ \\
\hline & Contribution of ideas to KNP and local government in mangrove management & X55 \\
\hline \multirow{5}{*}{$\begin{array}{l}\text { Concern to mangrove ecosystem } \\
\text { (X6) }\end{array}$} & Knowledge that mangrove forests need to be preserved & X61 \\
\hline & Participation in mangrove conservation activities held by KNP management & X62 \\
\hline & Independently ever do mangrove conservation activities & X63 \\
\hline & Invite fellow local people to preserve mangroves & X64 \\
\hline & The closeness of fellow citizens in mangrove conservation & X65 \\
\hline \multirow{5}{*}{$\begin{array}{l}\text { Response to the utilization of } \\
\text { mangrove ecosystem for ecotourism } \\
\text { (Y1) }\end{array}$} & Knowledge of ecotourism in mangrove forests & Y11 \\
\hline & KNP mangrove potential can be used as a tourist attraction & $\mathrm{Y} 12$ \\
\hline & Knowing that the mangrove will be a tourist destination by KNP management & Y13 \\
\hline & Involvement in ecotourism activities in mangrove forests & Y14 \\
\hline & Interest in ecotourism in mangroves KNP & $\mathrm{Y} 15$ \\
\hline
\end{tabular}

\section{Data analysis}

This research was conducted through qualitative and quantitative descriptive approaches. Data analysis of the questionnaire results refers to the Social Capital Assessment Tool (SCAT) (Krishna and Shrader 1999) with minor modifications. Social capital was categorized into five levels: very low (45-81), low (82-118), moderate (119155), high (156-192), and very high (193-225). The interval value of each level was calculated based on the maximum (225) and minimum value (45) of all social capitals. The correlation among the community's social capital elements was assessed to identify the mangrove ecosystem services for ecotourism. The elements of social capital observed in this research were trust, social norms, social networks, involvement, and concern of the community. The correlations among the variables of the social capital element were analyzed by PLS-SEM (Partial Least Square-Structural Equation Modeling) using the SmartPLS 3 to determine the social capital factors triggering the mangrove ecotourism. This model performs beta values of path coefficient that describe the greater the value, the more influential. T-test for interpreting the relationship between variables is if the value of $\mathrm{T}$ count > T-table with $(\alpha) 0.05$ (T-table $=1,96)$, it comes as a real effect or a significant variable to another variable.

\section{RESULTS AND DISCUSSION}

\section{Socio-economic characteristics of the respondents}

The majority of household respondents that participated in this survey were male. They accounted for $67 \%$ of the total respondents. Most of the respondents (58\%) were within 40 years and below. The educational background of the respondents was graduated from elementary school (45\%), junior high school (25\%), and senior high school (19\%). Most of the monthly income of the respondents was IDR 1,000,000.00 and below (49\%). About 40\% (199 households) of the total respondents reported the extraction of mangrove resources as their full-time occupation. The summary of the socio-economic characteristics of the respondents in the five villages is presented in Table 2. 
Table 2. Summary of the socio-economic background of the survey respondents

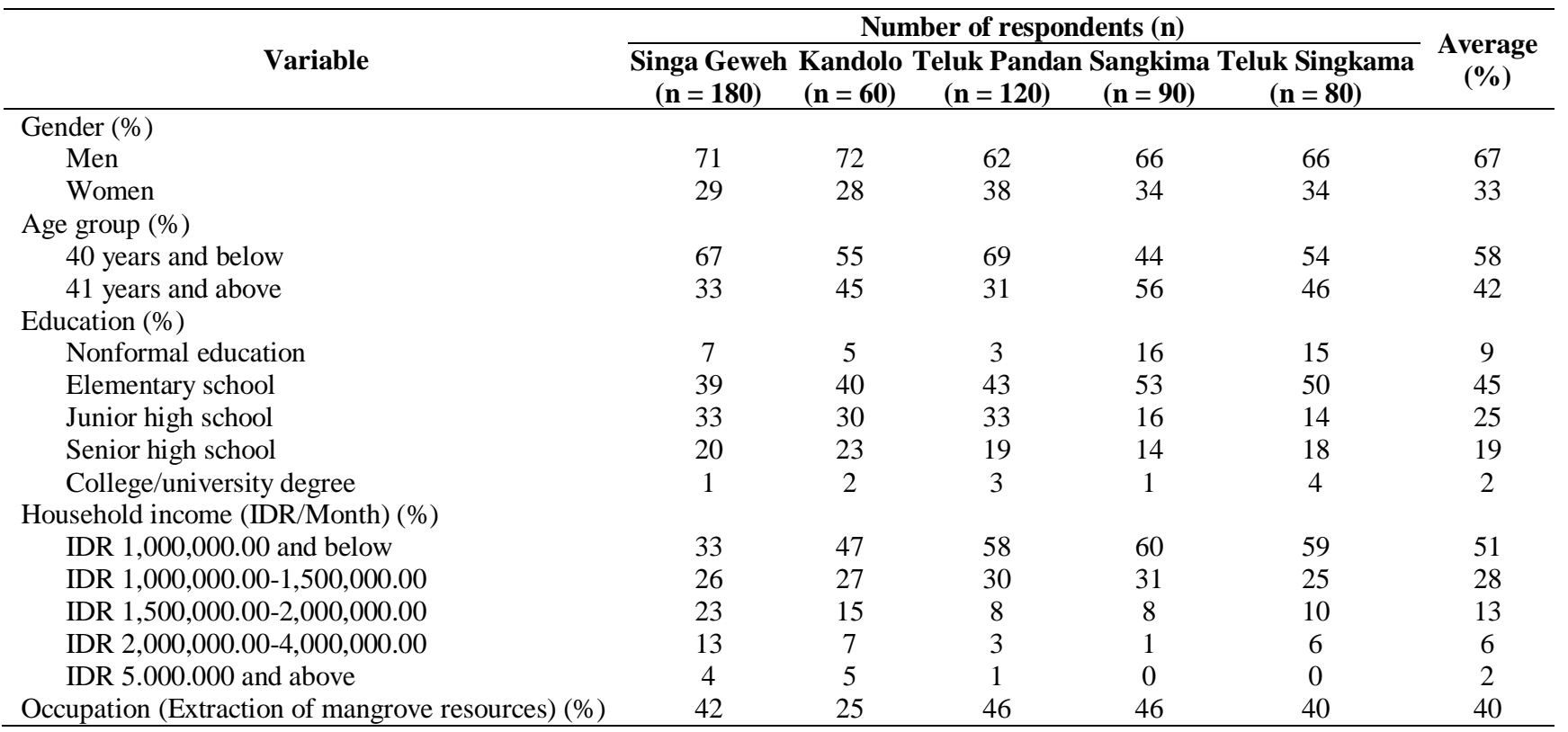

The socio-economics of the community in the five villages were relatively low, especially seen from the level of productive age, income, and education. These three things can affect social capital related to community awareness to support mangrove conservation. The people who settle down in these five villages have lived in KNP for decades. They are mostly migrants from outside Kalimantan. This condition influenced the cultural values and local wisdom, which can impact low norms and trust in social capital. Vayda and Sahur (2005) classified settlers in KNP by 3 regions, namely (i) Teluk Pandan; it was mentioned that Bugis settlers from Bone, South Sulawesi, first came in the mid-1960s, (ii) Selimpus/Kandolo area, first settled in 1974 and developed in 1977 by Bugis tribe and (iii) Sangkima area, first settled in 1924 by Bugis tribe. At that time, Sangkima was also a shifting cultivator for indigenous people, and both tribes were assimilated and settlers more and more in 1954 and 1960. According to BTNK (2005), the three villages are developed. The Governor of East Kalimantan Province has recognized them by defining them as the definitive village (Teluk Pandan, Sangkima, and Sangatta Selatan) through Decree number 06 of 1997 dated 30 April 1997. In its development, Desa Sangatta Selatan is divided into two villages, Desa Sangatta Selatan and Singa Geweh with the Decision of East Kalimantan Governor number 410.44/K.452/1999.

The local government and KNP management unit must think about how to improve the socio-economic life of the community in the conservation area. There are around 199 respondents directly related to KNP mangroves; this is a high potential in community empowerment, especially for mangrove ecotourism programs. Ecotourism certainly cannot stand alone and must be supported by other sectors such as the creative economy that can be developed and collaborated with stakeholders such as companies, local governments, academics, and non-government organizations. Hakim et al. (2017) stated mangroves are important resources, and nature-based tourism became a strategy for mangrove conservation. The success of mangrove tourism in the studied area could be due to a combination of factors, including mangrove site accessibility, local community involvement, the quality of mangrove ecosystems, and the availability of mangrove tourism programs.

\section{Social capital valuation}

Assessment by the scoring method to social capital in five villages showed that some elements of the social capital have low value, such as trust, social networking, and social norm, with an average value above 19 . Generally, the five villages have not supported the strength of the social capital, including the responses of respondents to mangrove services to ecotourism scored 17.8. The strength of the social capital in this study was in a low category, with an average value of 110.5 (ranging from 82 to 118) (Table 3). The elements of trust social norm in Teluk Singkama and Kandolo had higher scores than the other three villages. The networking elements in Teluk Pandan and Kandolo villages were higher than the other three villages. Elements of community involvement concerning mangrove and mangrove services to ecotourism in Kandolo and Sangkima were higher than in the other three villages. Respondents from the village of Sangkima had a deep concern for mangroves because they are the closest village to mangrove forests and tourism location on the coast of Teluk Lombok KNP. The Kandolo village also had a deep concern for mangroves for ecotourism services because they have access to the mangroves in Teluk Kaba KNP. 
Table 3. Minimal, maximal, and mean scores of the social capital variables

\begin{tabular}{lrrr}
\hline \multirow{2}{*}{ Social capital variables } & \multicolumn{2}{c}{ Mean score } & \multirow{2}{*}{ Mean } \\
\cline { 2 - 3 } & Min. & Max. & \\
\hline Education level & 2.3 & 2.8 & 2.6 \\
Income level & 1.5 & 2.3 & 1.8 \\
Trust & 16.9 & 22.4 & 20.5 \\
Social Networking & 16.6 & 20.8 & 19.3 \\
Social norm & 16.5 & 22.0 & 20.1 \\
Community involvement & 12.5 & 14.9 & 13.9 \\
Concern to mangrove & 12.8 & 17.8 & 14.5 \\
Mangrove services to ecotourism & 17.0 & 18.6 & 17.8 \\
Mean & 96.0 & 121.6 & 110.5 \\
\hline
\end{tabular}

The PLS-SEM (Partial Least Square-Structural Equation Modeling) analysis was carried out to examine the relation of indicator influence on each variable of the social capital element. The PLS-SEM has been widely used in the social sciences and was recently introduced into ecological studies (Peppler-Lisbach et al., 2015; Miguel et al., 2017). PLS is related to Principal Components Analysis (PCA), but additionally, it allows us to capture information on the relationship between predictive and target variables (Bryce et al., 2016). Based on this analysis, the Average Variance Extracted (AVE) for this study was higher than the value of 0.50 (Table 4), and the internal consistency reliability is higher than the recommended value (Hair et al. 2014; Ghozali 2014; Sözbilir 2018).

Evaluation of the initial measurement model found that the variable indicator could not reflect the construct of the latent variables. The variable had a loading factor value less than 0.5 , which needs re-specification by issuing an indicator variable that did not meet the eligibility criteria to improve the validity and reliability of the model. Out of 35 total indicators, several should be deleted for each village, fourteen indicators in Teluk Singkama, ten indicators in Singa Geweh, five in Kandolo, and Teluk Pandan, and four indicators in Sangkima. After the model was re-specified, the PLS algorithm process eventually gave the results that matched the criteria of convergence validity test on the measurement model. The AVE (>0.5) showed that all variables at various significant levels had positive correlations. Composite Reliability analysis $(>0.7)$ can state that the research model was valid and reliable (Table 4).
Social capital owned by individuals or communities is an important resource in an ecosystem that can improve the quality of ecosystem services. The stronger the social capital, the stronger the community's support for sustainable ecosystem services. The social capital tested in this study is represented by six variables, as presented in Table 5. The test had a significance level above the t-table ( $\alpha$ 0.05; t-table 1.96). Several hypotheses do not support mangrove forests for ecotourism. The community or respondents in five villages were concerned about mangrove or mangrove services to ecotourism. Then, variable social norms supporting mangrove ecotourism were found in the two villages, i.e., Teluk Pandan and Teluk Singkama villages.

Many variables were not significant based on the analysis of respondents in each village (Table 5). Furthermore, analysis for the entirety (530 respondents) was carried out to clearly know the significant influence of the six latent variables for ecotourism mangrove services. The results were analyzed with the PLS program to respecify the matched criteria to the convergence validity test on the measurement model (Figure 2). The evaluation of the measurement model through the load factor analysis, average variance extracted analysis value, cross-loading analysis, and composite reliability analysis can state that the research model is generalized to all objects; the research model is valid and reliable. The community involvement, social norm, and trust variables had no positive effect or were not significant to the utilization of mangrove services for ecotourism (Table 6). The overall analysis of the respondents gave slightly different results than the respondents' analysis of each village. One variable was a concern to mangroves, which positively influenced the four villages. While the networking variable had a positive impact in one village, the education and income levels variable had no positive influence in all villages.

The previous research also discovered the low social capital strength (Oktadiyani et al., 2013). The study explains the value of social capital for Kabo Jaya in Swarga Bara village is 173 (enough) and Dusun G III in Singa Gembara village is 159 (not enough). The weak social capital will dim the spirit of mutual cooperation, exacerbate poverty, increase unemployment and crime, and hinder efforts to improve human well-being (Nababan et al., 2016).

Table 4. Assessment of the measurement model (means, AVE, Composite Reliability=CR)

\begin{tabular}{|c|c|c|c|c|c|c|c|c|c|c|c|c|c|c|c|}
\hline \multirow{2}{*}{ Variables } & \multicolumn{3}{|c|}{ Singa Geweh } & \multicolumn{3}{|c|}{ Kandolo } & \multicolumn{3}{|c|}{ Teluk Pandan } & \multicolumn{3}{|c|}{ Sangkima } & \multicolumn{3}{|c|}{ Teluk Singkama } \\
\hline & Mean & AVE & CR & Mean & AVE & CR & Mean & AVE & CR & Mean & AVE & CR & Mean & AVE & CR \\
\hline (X1) & 2.49 & 0.65 & 0.79 & 2.35 & 0.79 & 0.86 & 2.18 & 0.70 & 0.82 & 1.91 & 0.75 & 0.86 & 2.04 & 0.67 & 0.80 \\
\hline (X2) & 2.81 & 0.62 & 0.87 & 3.74 & 0.52 & 0.84 & 3.51 & 0.54 & 0.88 & 3,5 & 0.75 & 0.90 & 3.54 & 0.60 & 0.75 \\
\hline (X3) & 2.76 & 0.87 & 0.95 & 3.46 & 0.55 & 0.86 & 3.35 & 0.64 & 0.89 & 3.30 & 0.51 & 0.86 & 3.32 & 0.57 & 0.80 \\
\hline (X4) & 2.75 & 0.67 & 0.89 & 3.67 & 0.52 & 0.84 & 3.43 & 0.52 & 0.84 & 3.42 & 0.51 & 0.85 & 3.45 & 0.60 & 0.75 \\
\hline (X5) & 2.49 & 0.62 & 0.83 & 2.99 & 0.74 & 0.92 & 2.83 & 0.65 & 0.88 & 3.04 & 0.68 & 0.89 & 2.59 & 0.58 & 0.81 \\
\hline (X6) & 2.68 & 0.57 & 0.80 & 3.02 & 0.52 & 0.80 & 2.68 & 0.60 & 0.82 & 3.56 & 0.52 & 0.83 & 2.56 & 0.51 & 0.81 \\
\hline (Y1) & 3.40 & 0.70 & 0.92 & 3.71 & 0.62 & 0.89 & 3.37 & 0.68 & 0.91 & 3.72 & 0.66 & 0.91 & 3.59 & 0.60 & 0.88 \\
\hline
\end{tabular}

Note: $*$ ) according to rule of thumb (AVE $>0.5 ; \mathrm{CR}>0.7)$ 
Table 5. Significance test model after re-specification in the five villages

\begin{tabular}{|c|c|c|c|}
\hline \multirow{2}{*}{ Latent variables hypotheses } & \multicolumn{3}{|c|}{ Singa Geweh (180 respondent) } \\
\hline & Path coefficients & t-Value & Supported? \\
\hline Community involvement-> Mangrove services to ecotourism & 0.147 & 1.854 & No \\
\hline Concern to mangrove-> Mangrove services to ecotourism & 0.254 & 3.541 & Yes \\
\hline Education and income levels-> Mangrove services to ecotourism & 0.086 & 1.394 & No \\
\hline Networking-> Mangrove services to ecotourism & 0.132 & 1.728 & No \\
\hline Social norms-> Mangrove services to ecotourism & 0.172 & 1.934 & No \\
\hline \multirow[t]{2}{*}{ Trust-> Mangrove services to ecotourism } & 0.045 & 0.490 & No \\
\hline & \multicolumn{3}{|c|}{ Kandolo (60 respondents) } \\
\hline Community involvement-> Mangrove services to ecotourism & -0.111 & 0.532 & No \\
\hline Concern to mangrove-> Mangrove services to ecotourism & 0.417 & 2.436 & Yes \\
\hline Education and income levels-> Mangrove services to ecotourism & 0.197 & 1.446 & No \\
\hline Networking-> Mangrove services to ecotourism & 0.025 & 0.135 & No \\
\hline Social norms-> Mangrove services to ecotourism & -0.114 & 0.632 & No \\
\hline \multirow[t]{2}{*}{ Trust-> Mangrove services to ecotourism } & 0.220 & 0.930 & No \\
\hline & \multicolumn{3}{|c|}{ Teluk Pandan (120 respondent) } \\
\hline Community involvement-> Mangrove services to ecotourism & 0.165 & 2.006 & Yes \\
\hline Concern to mangrove-> Mangrove services to ecotourism & 0.383 & 3.779 & Yes \\
\hline Education and income levels-> Mangrove services to ecotourism & 0.078 & 1.029 & No \\
\hline Networking-> Mangrove services to ecotourism & 0.101 & 1.013 & No \\
\hline Social norms-> Mangrove services to ecotourism & 0.185 & 2.085 & Yes \\
\hline \multirow[t]{2}{*}{ Trust-> Mangrove services to ecotourism } & -0.078 & 0.877 & No \\
\hline & \multicolumn{3}{|c|}{ Sangkima (90 respondents) } \\
\hline Community involvement-> Mangrove services to ecotourism & 0.166 & 1.366 & No \\
\hline Concern to mangrove-> Mangrove services to ecotourism & 0.005 & 0.036 & No \\
\hline Education and income levels-> Mangrove services to ecotourism & 0.126 & 1.179 & No \\
\hline Networking-> Mangrove services to ecotourism & 0.315 & 2.155 & Yes \\
\hline Social norms-> Mangrove services to ecotourism & -0.099 & 0.686 & No \\
\hline \multirow[t]{2}{*}{ Trust-> Mangrove services to ecotourism } & 0.278 & 2.289 & Yes \\
\hline & \multicolumn{3}{|c|}{ Teluk Singkama ( 80 respondent) } \\
\hline Community involvement-> Mangrove services to ecotourism & 0.037 & 0.215 & No \\
\hline Concern to mangrove-> Mangrove services to ecotourism & 0.395 & 3.142 & Yes \\
\hline Education and income levels-> Mangrove services to ecotourism & 0.067 & 0.681 & No \\
\hline Networking-> Mangrove services to ecotourism & 0.152 & 1.553 & No \\
\hline Social norms-> Mangrove services to ecotourism & 0.318 & 2.626 & Yes \\
\hline Trust-> Mangrove services to ecotourism & -0.030 & 0.238 & No \\
\hline
\end{tabular}

Table 6. The significance test model after re-specification to 530 respondents

\begin{tabular}{|c|c|c|c|}
\hline \multirow{2}{*}{ Latent variables hypotheses } & \multicolumn{3}{|c|}{ Result (530 respondents) } \\
\hline & Path coefficients & t-Value & Supported? \\
\hline Community involvement-> Mangrove services to ecotourism & 0.052 & 1.129 & No \\
\hline Concern to mangrove-> Mangrove services to ecotourism & 0.263 & 5.756 & Yes \\
\hline Education and income levels-> Mangrove services to ecotourism & 0.110 & 3.012 & Yes \\
\hline Networking-> Mangrove services to ecotourism & 0.193 & 3.563 & Yes \\
\hline Social norm-> Mangrove services to ecotourism & 0.080 & 1.412 & No \\
\hline Trust-> Mangrove services to ecotourism & 0.085 & 1.463 & No \\
\hline
\end{tabular}

Ecosystems results from complex interactions between ecological and social processes. People affect ecosystems' capacity to deliver services that contribute to the well-being of humans and their resilience (Fedele et al., 2017). The values of mangrove ecosystem services are highly variable across study sites due to other factors, the biophysical characteristics of the site, and the socio-economic characteristics of the beneficiaries of ecosystem services (Brander et al., 2012). Involving local communities in mangrove management is an effective way of maintaining and enhancing the protection function of the mangrove forest while providing livelihood for local people (Schmitt and Norman 2015). Future governance models must involve partnerships between local custodians of mangroves and beneficiaries of the services (Lee et al., 2014). Community participation is needed to develop and preserve mangrove forests in the conservation areas. (Suprakto et al. 2014). 


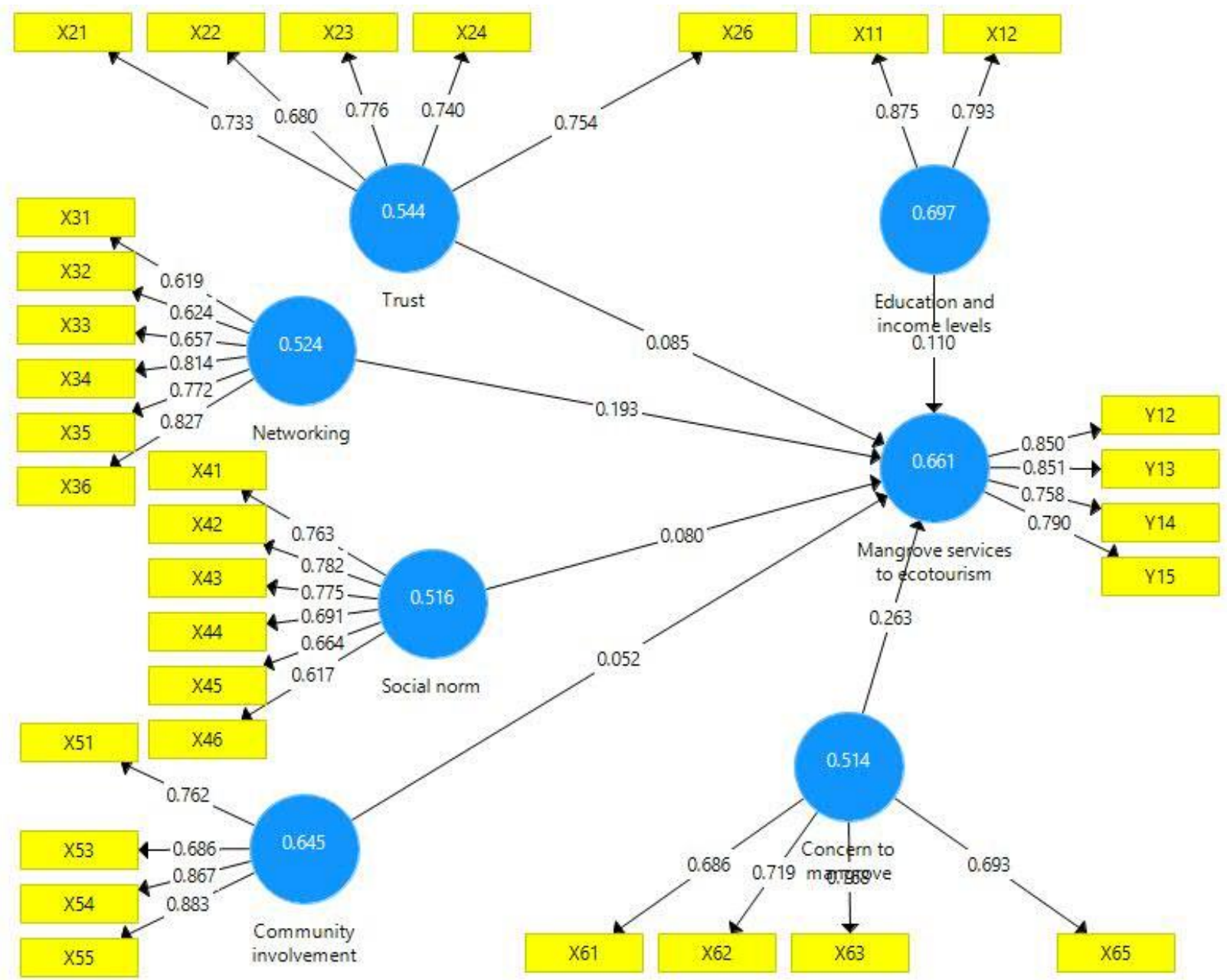

Figure 2. The convergent validity of each construct factor loadings after the re-specification

The main challenges to restoring and managing the mangrove forests are socio-economic conditions and land conflict between society, KNP, and local government (Gunawan and Sayektiningsih 2012). Community-based mangrove management will reduce conflicts. In Thailand, stand structure was superior in mangrove forests managed by communities rather than in mangrove forests are claimed for state management (Sudtongkong and Webb 2008). Mangrove tourism programs could support a conservation program. It is also crucial to involve and strengthen the participation of local communities surrounding mangrove areas. In Indonesia, national parks are the pioneer for mangrove-based recreation. In East Java, efforts to involve mangrove ecosystems in tourism packages were promoted in Alas Purwo National Park, Meru Betiri National Park, and Baluran National Park (Hakim et al., 2017). KNP in the future should be able to develop like the national park in Java. Although the social capital was still weak in supporting mangrove ecotourism, such as community involvement and trust, it can still be improved by multi-stakeholder cooperation.

In conclusion, natural tourism is one of the possible activities to be promoted in mangrove areas of national parks to increase local communities' role and preserve mangrove forests. Efforts to involve communities in mangrove conservation and tourism development were relatively poor in KNP. The low level of community involvement can be caused by weak information, socialization, and financing for activities related to mangroves in KNP. Low trust level was also associated with low community involvement and social norms support. Low social norms can occur because the values of local wisdom and local culture in the community are not well maintained. Support from the local government, KNP management units, NGOs, and surrounding companies should be improved to strengthen the community's social capital that can positively affect the conservation of mangroves and ultimately increase human well-being. Community involvement was also affected by the trust level and community knowledge related to social norms and other regulations related to national park management. Preservation and development of mangrove tourism efforts in the national park would need a particular approach for the community around the mangrove forest. The socioecology approach that offers a comprehensive theoretical base needs to be well developed for strategy defines the utilization of the mangrove ecosystem service for ecotourism in the national park. An interdisciplinary 
approach with mixed methods to determine ecological perspectives can be a useful research strategy to improve the social function of an ecosystem system.

\section{ACKNOWLEDGEMENTS}

The authors appreciate the KNP management unit who has supported and provided opportunities for the author to conduct this research. The author also thanks Prof. Erny Poedjirahajoe. Acknowledgments were also conveyed to the lecturers and college students of STIPER East Kutai in Sangatta, who stoutly assisted this study. Thank is also delivered to the Ministry of Research, Technology and Higher Education of the Republic of Indonesia through the Directorate-General for Research and Development, which has encouraged the improvement of the quality and quantity of the research outcomes by providing the incentive for the authors.

\section{REFERENCES}

Asmin F, Darusman D, Ichwandi I, Suharjito D. 2017. Social capital of Parak and Rimbo Management in West Sumatera. J Trop For Manag 23 (3): 140-149. DOI: 10.7226/jtfm.23.3.140.

Barnes-Mauthe M, Kirsten LLO, Luke MB, Bienvenue Z, Thomas AO, Pietervan B. 2015. Social capital as an ecosystem service: Evidence from a locally managed marine area. Ecosyst Serv 16: 283-293. DOI: 10.1016/j.ecoser.2014.10.009.

Bismark M, Iskandar S. 2002. Kajian total populasi dan struktur sosial bekantan (Nasalis larvatus) di Taman Nasional Kutai, Kalimantan Timur. Buletin Penelitian Hutan 631:17-29. [Indonesian]

Brander LM, Wagtendonk AJ, Hussain SS, McVittie A, Verburg P H, de Groot RS, van der Ploeg S. 2012. Ecosystem service values for mangroves in Southeast Asia: A meta-analysis and value transfer application. Ecosyst Serv 1 (1): 62-69. DOI: 10.1016/j.ecoser.2012.06.003.

Bryce R, Irvine KN, Church A, Fish R, Ranger S, Jasper, Kenter O. 2016. Subjective well-being indicators for large-scale assessment of cultural ecosystem services. Ecosyst Serv 21: 258-269. DOI $10.1016 / \mathrm{j}$.ecoser.2016.07.015.

BTNK. 2005. Data Dasar Taman Nasional Kutai. Balai Taman Nasiona Kutai, Bontang, Kalimantan Timur. [Indonesian]

Budiarsa AA, Rizal S. 2013. Pemetaan dan analisis tingkat kerusakan hutan mangrove di Taman Nasional Kutai berdasarkan data citra setelit Landsat ETM dan kerapatan vegetasi. Jurnal Ilmu Perikanan Tropis 19 (1): 54-61. [Indonesian]

Budiarsa AA, Rizal S. 2014. Community structure of macrozoobenthos in mangrove ecosystem, Kutai National Park, East Kalimantan. Intl J Sci Eng 7 (1): 91-94. DOI: 10.12777/ijse.7.1.91-94.

Fedele G, Locatelli B, Djoudi H. 2017. Mechanisms mediating the contribution of ecosystem services to human well-being and resilience. Ecosyst Serv 28: 43-54. DOI 10.1016/j.ecoser.2017.09.011.

Ghozali I. 2014. Structural Equation Modeling: Metode Alternatif dengan Partial Least Squares (PLS). Universitas Diponegoro, Semarang. [Indonesian]

Giri C, Ochieng E, Tieszen LL, Zhu Z, Singh A, Loveland T, Masek J, Duke N. 2011. Status and distribution of mangrove forests of the world using earth observation satellite data. Glob Ecol Biogeogr 20 (1): 154-159. DOI: $10.1111 / \mathrm{j} .1466-8238.2010 .00584 . \mathrm{x}$

Grootaert C, Narayan D, Jones VN, Woolcock M. 2003 Measuring Socia Capital: An Integrated Questionnaire. The World Bank. Social Development Family, Environmentally and Socially, Sustainable
Development Network, Washington, DC. DOI: 10.1596/0-82135661-5.

Grootaert C, van Bastelaer T. 2001. Understanding and Measuring Social Capital. The World Bank. Social Development Family, Environmentally and Socially, Sustainable Development Network, Washington, DC.

Gunawan W, Sayektiningsih T. 2012. Socio-economic challenges on mangrove restoration in Kutai National Park, East Kalimantan, Indonesia. Proceedings of the 1st ASEAN Congress on Mangrove Research and Development. Manila, Philippines, 3-7 December 2013.

Gunawan W, Sayektiningsih T. 2014. Restorasi dan Pelestarian Ekosistem Mangrove di Taman Nasional Kutai. Warta Konservasi Lahan Basah, Wetlands International dan Ditjen PHKA, Departemen Kehutanan. [Indonesian]

Hair JF, Hult GTM, Ringle CM, Sarstedt M. 2014. A primer on partial least squares structural equation modeling (PLS-SEM). Sage, Thousand Oak, USA.

Hakim L, Siswanto D, Nakagoshi N. 2017. Mangrove conservation in East Java: The ecotourism development perspectives. J Trop Life Sci 7 (3): 277-285. DOI: 10.11594/jtls.07.03.14.

Jakpar S, Goh SNA. 2012. Examining the product quality attributes that influence customer satisfaction most when the price was discounted: A case study in Kuching Sarawak. Intl J Business Soc Sci 3 (23): 221-236.

Krishna A, Shrader E. 1999. Social Capital Assessment Tool (SCAT). Conference on Social Capital and Poverty Reduction. The World Bank, Washington, D.C

Lee SY, Primavera JH, Guebas FD, Mc Kee K, Bosire JO, Cannicci S, Diele K, Fromard F, Koedam N, Marchand C, Mendelssohn I, Mukherjee N, Record S. 2014. Ecological role and services of tropical mangrove ecosystems: a reassessment. Glob Ecol Biogeogr 23 (7): 726-743. DOI: $10.1111 /$ geb.12155.

Limberg GA, Moeliono M, Indriatmoko $\mathrm{Y}$, Iwan $\mathrm{R}$, Nutomo NA, Purwanto E, Mulyana A. 2009. Incentives to conserve or convert? Can conservation compete with coal in Kutai National Park, Indonesia? Intl J Biodiv Sci Manag 5 (4): 190-198. DOI: 10.1080/17451590903525226.

Luck DJ, Rubin RS. 1987. Marketing Research. 7th ed. Prentice-Hall, Englewood Cliffs, N.J.

Nababan EJK, Qurniati R, Kustanti A. 2016. Modal sosial pada pengelolaan dan pelestarian hutan mangrove di Kecamatan Labuhan Maringgai Kabupaten Lampung Timur. Jurnal Silva Lestari 4 (2): 89100. DOI: 10.23960/jsl2489-100. [Indonesian]

Noor YR, Khazali M, Suryadiputra I NN. 2006. Panduan Pengenalan Mangrove di Indonesia. Wetlands International dan Ditjen PHKA, Bogor. [Indonesian]

Oktadiyani P, Harini EKS, Arzyana MS. 2013. Modal sosial masyarakat di kawasan penyangga Taman Nasional Kutai (TNK) dalam pengembangan ekowisata. Jurnal Media Konservasi 18 (1): 1-9. [Indonesian]

Sözbilir F. 2018. The interaction between social capital, creativity, and efficiency in organizations. Thinking Skills Creativity 27: 92-100. DOI: 10.1016/j.tsc.2017.12.006.

Sudtongkong C, Edward LW. 2008. Outcomes of state-vs. communitybased mangrove management in Southern Thailand. Ecol Soc 13 (2): 27. DOI: 10.5751/ES-02531-130227.

Suprakto B, Soemarno, Marsoedi, Arfiati D. 2014. Development of mangrove conservation area based on land suitability and environmental carrying capacity (Case study from Probolinggo Coastal Area, East Java, Indonesia). Intl J Ecosyst 4 (3): 107-118.

Suwarto, Prasetyo LB, Kartono AP. 2016. Habitat suitability for Proboscis Monkey (Nasalis larvatus Wurmb, 1781) in the mangrove forest of Kutai National Park, East Kalimantan. Bonorowo Wetl 6 (1): 12-25. DOI: 10.13057/bonorowo/w060102.

Vayda AW, Sahur A. 2005. Bugis Settlers in East Kalimantan on Kutai National Park. Center for International Forestry Research (CIFOR). UNDP/UNESCO/Government of Indonesia Project INS/93/004. Jakarta.

Wijaya NI. 2011. Pengelolaan Zona Pemanfaatan Ekosistem Mangrove melalui Optimasi Pemanfaatan Sumberdaya Kepiting Bakau (Scylla serrata) di Taman Nasional Kutai Provinsi Kalimantan Timur. [Dissertation]. Sekolah Pascasarjana IPB, Bogor. [Indonesian] 